\title{
NEW RECORDS OF CYDALIMA PERSPECTALIS (WALKER, 1859) (LEPIDOPTERA, CRAMBIDAE) FROM ALBANIA AND KOSOVO
}

\section{Donard Geci ${ }^{1}$, Milaim Musliu ${ }^{2}$, Astrit Bilalli ${ }^{2}$ \& Halil Ibrahimi ${ }^{1 *}$}

${ }^{1}$ Department of Biology, Faculty of Mathematics and Natural Sciences, Hasan Prishtina University of Prishtina, Mother Theresa Street p.n., 10000 Prishtina, Republic of Kosovo

(*corresponding author: halil.ibrahimi@uni-pr.edu)

2Faculty of Agribusiness, University “Haxhi Zeka”, “UÇK” street, 30000 Pejë, Republic of Kosovo

Geci, D., Musliu, M., Bilalli, A. \& Ibrahimi, H.: New records of Cydalima perspectalis (Walker, 1859) (Lepidoptera, Crambidae) from Albania and Kosovo. Nat. Croat., Vol. 29, No. 1, 135-138, Zagreb, 2020.

In this contribution, we report new records of the invasive moth Cydalima perspectalis (Walker, 1859) from Albania and Kosovo. Previously, it has been reported from all over the European continent, including all Balkan countries. During this investigation it has been observed at two sites in Albania, located in Kukës and Kavajë municipalities. From Kosovo we report four new sites where this species was observed, belonging to Klinë, Pejë and Prishtinë municipalities.

Keywords: Balkan Peninsula, Box tree moth, invasive species, Buxus

Geci, D., Musliu, M., Bilalli, A. \& Ibrahimi, H.: Novi nalazi Cydalima perspectalis (Walker, 1859) (Lepidoptera, Crambidae) iz Albanije i Kosova. Nat. Croat., Vol. 29, No. 1, 135-138, Zagreb, 2020.

U ovom priopćenju donosimo nove nalaze invazivne vrste šimširovog moljca Cydalima perspectalis (Walker, 1859) iz Albanije i Kosova. Dosad je bio zabilježen širom cijele Europe, uključujući sve zemlje Balkana. Tijekom ovog istraživanja zabilježen je na dva lokaliteta u Albaniji, na području općina Kukës i Kavajë. Na Kosovu donosimo četiri nova lokaliteta gdje je zabilježena ova vrsta, a koja se nalaze u općinama Klina, Peć i Priština.

Ključne riječi: Balkanski poluotok, šimširov moljac, invazivna vrsta, Buxus

The invasive box tree moth Cydalima perspectalis (Walker, 1859) which is native to Asia (HAmpson, 1896; InOue, 1982; PARK, 2008) was introduced to Europe through ornamental plants more than a decade ago. It is a phytophagous insect with two different adult forms (Fig. 1), the white one being the most common, the melanic form found to a lesser degree (MALly \& Nuss, 2010). The larvae mostly feed on the leaves, but also bark, of Buxus species. When the number of larvae is huge they can cause deflorations and at the end the withering and death of plants (Mally \& Nuss, 2010). In Asia, Cydalima perspectalis has three to five generations (WAN et al., 2014), while in Europe it has only two generations (NАсамво et al., 2013). Adults have a lifespan of approximately up to two weeks. Adult moths are good flyers and their flight occurs at the end of May or beginning of June (Olean et al., 2017). During the daytime they like to rest on box trees or surrounding plants.

It was reported from all countries in the Balkan Peninsula: Bosnia and Herzegovina (Ostojıć et al., 2015), Bulgaria (Beshrov et al., 2015), Croatia (Koren \& Č́rne, 2012), Greece (Strachinis et al., 2015), Hungary (SÁfián \& Horvát, 2011), Montenegro (HrN- 
Čić \& RAdonjić, 2014), Romania (Szekely et al., 2011), Serbia (Konjević et al., 2015), Slovenia (SELjAK, 2012; MatošEvić, 2013), not long after its first record in Europe (BILLEN, 2007). It has been reported only recently from Kosovo (Geci \& IBrahimi, 2018), North Macedonia (NAČeski et al., 2018) and Albania (RAineri et al., 2017; Beshrov \& NAHIRNIĆ, 2019).

During this investigation, it has been observed from two localities in Albania: the first one in Kukës Municipality ( $42.066184^{\circ} \mathrm{N}, 20.432038^{\circ} \mathrm{E}, 355 \mathrm{~m}$ a.s.l.) and the second one in Kavajë Municipality (41.189000 ${ }^{\circ} \mathrm{N}, 19.558732{ }^{\circ} \mathrm{E}, 52 \mathrm{~m}$ a.s.1.) (Fig. 2). Both sites are located inside inhabited areas and $C$. perspectalis has been observed near light sources. In each case a single specimen of the melanic form was observed.

In this contribution we also report four new sites of $C$. perspectalis from Kosovo (Fig. 2): the first one in Klinë town (42.62558 ${ }^{\circ} \mathrm{N}, 20.580891{ }^{\circ} \mathrm{E}, 415 \mathrm{~m}$ a.s.l.), the second one in Pejë town (42.662866 ${ }^{\circ} \mathrm{N}, 20.330314{ }^{\circ} \mathrm{E}, 480 \mathrm{~m}$ a.s.l.), the third one in Prishtinë town (42.655982 ${ }^{\circ} \mathrm{N}, 21.162873{ }^{\circ} \mathrm{E}, 605 \mathrm{~m}$ a.s.1.) and the fourth one in Bardhosh village, Prishtinë Municipality $\left(42.716087^{\circ} \mathrm{N}, 21.147306^{\circ} \mathrm{E}, 614 \mathrm{~m}\right.$ a.s.l.). The first three sites are

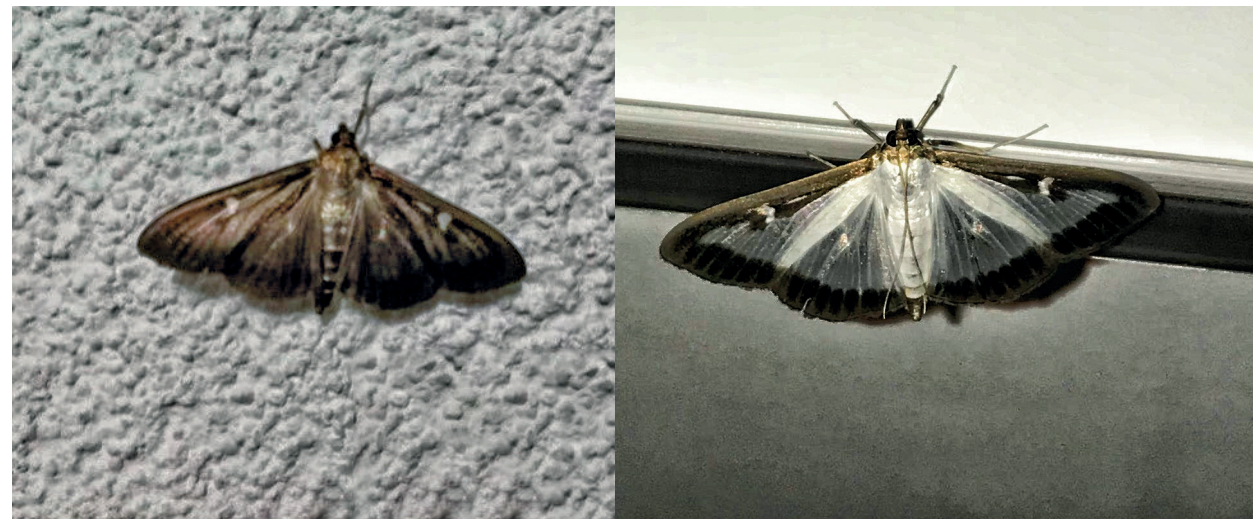

Fig. 1. Two different forms of Cydalima perspectalis, left - melanic form from Klinë (photo by M. Musliu), right - white form from Prishtinë (photo by D. Geci).

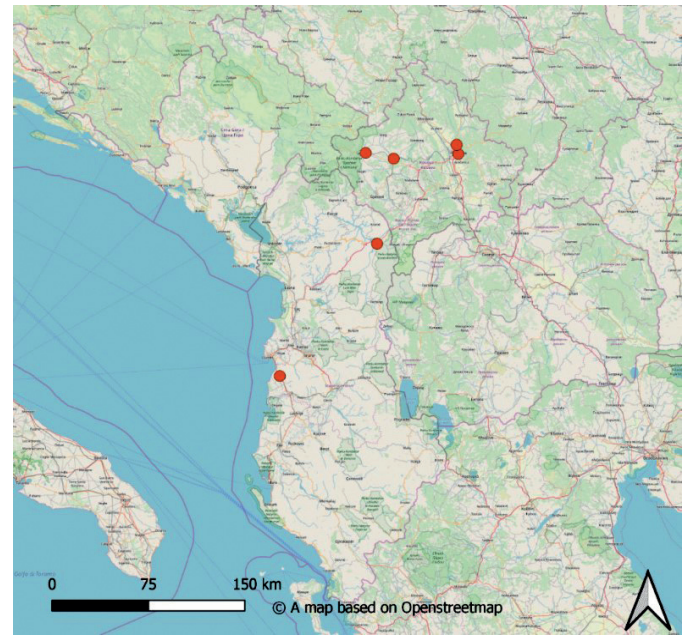

Fig. 2. Sites where Cydalima perspectalis was observed in Albania and Kosovo during this investigation. 
in urban areas while the fourth one is located in a rural area, a few kilometers from Prishtina town. In Klinë, both forms were observed, while in other localities single specimens of the white form were observed.

All these records of $C$. perspectalis from Albania and Kosovo (Fig. 2) are the result of casual observations and it is still not known how widespread is this invasive species in both countries. However, considering the increased frequency of observations and existence of favorable habitats in both countries, we can conclude that it has either invaded large proportions of their territories or will do so soon.

Received January 29, 2020

\section{REFERENCES}

Beshrov, S., Plant, C. W., Nahirnić, A., King, A. \& Jakšić, P., 2020: A contribution to knowledge of Balkan Lepidoptera: moths collected in May - June 2018 in Austria, Slovenia, Serbia, North Macedonia and Albania. Entomologist's Records Journal 132, 24-45.

Beshiov, S. \& NAhirnić, A., 2019: A contribution to knowledge of the Balkan Lepidoptera: species collected in the autumn of 2018 in Albania (Macrolepidoptera with some Crambidae), Entomologist's Records Journal Var. 131, 66-102.

Beshoov, S., Abadjiev, S., \& Dimitrov, D., 2015: Cydalima perspectalis (Walker, 1859) (Lepidoptera: Pyraloidea:Crambidae: Spilomelinae), New Invasive Pest Moth In Bulgaria. The Entomologist's Record And Journal Of Variation 127, 18-22.

Billen, W., 2007: Diaphania perspectalis (Lepidoptera: Pyralidae) A new moth in Europe. Mitteilungen der Entomologischen Gesellschaft 57 (2-4), 135-137.

Geci, D. \& Ibrahimi, H., 2018: First record of the box tree moth Cydalima perspectalis (Walker, 1859) (Lepidoptera, Crambidae) from Kosovo. Nat. Croat., 27 (2), 343-345.

Hampson, G.F., 1896: Moths 4. The Fauna of British India,including Ceylon and Burma. Taylor \& Francis, London.Inoue H, 1982. Pyralidae. In: Moths of Japan 1, 2.

Hrnčić, S. \& Radonjıć, S., 2014: Cydalima perspectalis Walker (Lepidoptera: Crambidae) - nova invazivna tetočina šimšira u Crnoj Gori. Simpozij o zaštiti bilja u Bosni i Hercegovini, Teslić, 04. - 06.11.2014. godine, Zbornik rezimea. p. 24-25.

Inoue, H., Sugi, S., Kuroko, H., Moriuti, S. \& Kawabe, A., 1982: Moths of Japan Ko-dansha, Tokyo, Vol. 1, 307-404.

Koren, T. \& ČRne, M., 2012: The first record of the Box Tree Moth, Cydalima perspectalis (Walker, 1859) (Lepidoptera, Crambidae) in Croatia. Natura Croatica 21, 507-510.

Mally, R. \& Nuss, M., 2010: Phylogeny and nomenclature of the box tree moth, Cydalima perspectalis (Walker, 1859) comb. n. which was recently introduced into Europe (Lepidoptera: Pyraloidea: Crambidae: Spilomelinae). European Journal of Entomology 107(3), 93-400.

Nacambo, S., Leuthardt, F., Wan, H., Li, H., Haye, T., Baur, B., Weiss, R. M. \& Kenis, M., 2013: Development characteristics of the box-tree moth Cydalima perspectalis and its potential distribution in Europe. Journal of Applied Entomology 137, 1-13.

Načeski, S., Papazova-Anakieva, I., Ivanov, B., Lazarevska, S. \& Šurbevski, B., 2018: Occurrence Of The New Invasive Insect Cydalima perspectalis Walker On Box Tree In The Republic Of Macedonia. Contributions, Section of Natural, Mathematical and Biotechnical Sciences Vol. 39(2), 135-141.

Oltean, I. Hulujan, I. Hulujan, I.Varga, M. Tötös, S. \& Florian, T., 2017: Cydalima perspectalis Walker (Lepidoptera, Crambidae) a New Dangerous Pest Report on Buxus Sempervirens in Cluj Area. Bulletin USAMV series Agriculture 74(1).

Ostojić, I. Zovko, M. Petrović, D. \& Elez, D., 2015: New records of box tree moth Cydalima perspectalis (Walker, 1859) in Bosnia and Herzegovina. Radovi Poljoprivrednog Fakulteta Univerziteta u Sarajevu (Works of the Faculty of Agriculture University of Sarajevo) 60 (65-1), 139-143.

PARK, I.K., 2008: Ecological characteristic of Glyphodes perspectalis. Korean Journal of Applied Entomology 47, 299-301.

Raineri, V., Bonechi, F., Caracciolo, D., Cresta, P. \& M. Mariotti, 2017: Cydalima perspectalis (Walker, 1859) (Lepidoptera, Crambidae) and the threats for the nature 2000 habitat 5110 in Liguria (NW-Italy). Bollettino dei musei e degli istituti biologici dell'Universita di Genova 79, 215-236. 
SÁFí́N, S. \& HoRvát, B., 2011: Box Tree Moth - Cydalima perspectalis (Walker, 1859), new member in the Lepidoptera fauna of Hungary (Lepidoptera: Crambidae). Natura Somogyiensis 9, 245-246.

Seljak. G., 2012: Six new alien phytophagous insect species recorded in Slovenia in 2011. Acta Entomologica Slovenica 20(1), 31-44.

Strachinis, I., Kazilas, C., Karamaouna, F., Papanikolaou, N.E., Partsinevelos, G.K. \& Milonas, P.G., 2015: First record of Cydalima perspectalis (Walker, 1859) (Lepidoptera: Crambidae) in Greece. Hellenic Plant Protection Journal 8, 66-72.

SzéKely, L., Dincă, V. \& MinaI, C., 2011: Cydalima perspectalis (Walker, 1859), a new species for the Romanian fauna (Lepidoptera: Crambidae: Spilomelinae). Buletinul de Informare Entomologică 22, 3-4.

Wan, H. T., Haye, T., Kenis, M., Nacambo, S., XU, H., Zhang, F. \& LI, H., 2014: Biology and natural enemies of Cydalima perspectalis in Asia: Is there biological control potential in Europe. Jurnal of Applied Entomology 138, 715-722 . 